Nig. J. Biotech. Vol. 37(2): 84-94 (Dec. 2020)

ISSN: 01891731

Available online at

http://www.ajol.info/index.php/njb/index

and www.biotechsocietynigeria.org

DOI: https://dx.doi.org/10.4314/njb.v37i2.8

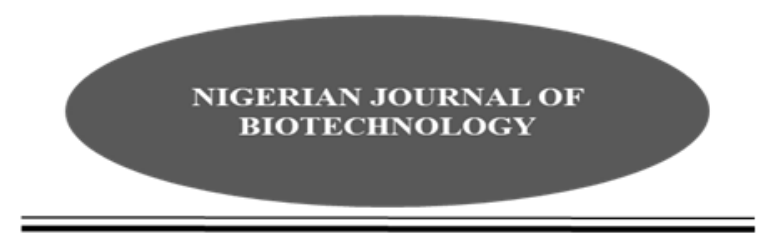

\title{
Isolation and Identification of Hydrocarbons- Degrading Bacteria from Panteka Stream, Kaduna, Nigeria, and Assessment of their Potential for Bioremediation
}

\author{
Nwagwu, E. C., Yilwa, V. M., Egbe, N. E. and Onwumere, G. B. \\ Department of Biological Sciences, Nigerian Defence Academy, Kaduna, Nigeria.
}

\begin{abstract}
Water bodies become hydrocarbon-polluted when petroleum and other toxic organic matters are discharged into them. Panteka, located in northern Kaduna, Nigeria, is home to Panteka market, which is an industrial hub where different kinds of automobile spare parts are sold and mechanic workshops are situated. The Panteka stream flows through an entry point at Rafin guza, through Panteka market and towards the National Eye Centre. The indiscriminate disposal of spent engine oils and the discharge of other untreated effluents from car servicing workshops into the Panteka stream can lead to hydrocarbon contamination. Consequently, there is a need to identify these hydrocarbons and determine the capability of bacteria isolated from the stream to degrade the hydrocarbon pollutants. Using the pour plate method, and Bushnell Haas agar supplemented with $1 \%$ used engine oil, five bacterial isolates with the potential to degrade hydrocarbons were identified as Streptococcus pnuemoniae, Klebsiella pneumoniae, Shigella dysenteriae, Streptococcus pyogenes and Salmonella enterica. Salmonella enterica was confirmed by 16S rRNA gene sequencing and Basic Local Alignment search tool (BLAST) with a similarity index of $99 \%$. The ability of the bacterial isolates to tolerate the spent engine oil was determined by turbidi metry. The results show that all the five bacterial isolates were able to tolerate the $1 \%(\mathrm{v} / \mathrm{v})$ concentration of the spent engine oil. The highest growth rates (O.D 0.565 and O.D 0.695) were obtained from the pure cultures of Streptococcus pyogenes and the mixed bacterial consortium, respectively. The potentials of the bacteria to degrade hydrocarbons in the stream was analysed using Gas Chromatography Flame Ionization Detector (GC-FID), and the results showed reduction of the Total Petroleum Hydrocarbon (TPH) content from $6,056 \mathrm{mg} / \mathrm{ml}$ to $100.17 \mathrm{mg} / \mathrm{ml}(98.3 \%$ degradation) after 28 days of treatment with the mixed bacterial culture. The hydrocarbon fractions degraded were $n$-Nonane, $n$-Decane, $n$ Undecane, n- Dodecane, n-Tridecane, n-Tetradecane, n-Heptadecane, Pristane, n-octadecane, Phytane, n-Eicosane, $n$-Tricosane, $n$-Tetracosane, $n$-Octacosane, $n$-Triacontane, n-Dotriacontane, $n$ Tritriacontane, n-Heptriacontane; while n-Pentadecane, n-Hexadecane, n-Nonadecane, nHeneicosane, n-Docosane, n-Pentacosane, n-Hexacosane, n-Heptacosane, n-Nonacosane, nHentriacontane, $n$-Tetratriacontane, $n$-Pentatriacontane, and $n$-Hexatriacontane were not degraded. This study shows that these bacterial strains isolated from the Panteka stream have great potential for bioremediation of the hydrocarbons found in the stream.
\end{abstract}

Keywords: Bioremediation, Panteka stream, Automobile workshop, Hydrocarbon pollution, Bacteria isolates Corresponding author's email: elizabethnwagwu@gmail.com Introduction

Stream water contamination by petroleum products is a serious problem, causing health and economic problems to those inhabiting or working in such environments. The villagers and people surrounding Panteka Stream use the stream for irrigation farming, fishing, and drinking purposes, both for humans and their cattle. The continuous unsanitary activities in and around the stream make its water unsafe for humans and animals. Auto mechanics and spare parts dealers in Panteka Market may introduce hydrocarbons into Panteka Stream by washing motor 
or engine parts contaminated with spent oil in the stream, thereby polluting the stream, and making it more hazardous to aquatic life and the users of the stream.

Engine oil is a lubricant and a petroleum product which consists of a base oil made of crude oil fraction and other additives. The additives function as corrosion inhibitors, anti foam agents, and antioxidants. Used motor oil is the existing brownto-black oily liquid removed from a motor vehicle during an oil change (Abdulsalam et al., 2013). When a given motor oil is used in a running vehicle, additional chemicals are built up in the oil at high temperatures and pressures (Dorsey et al., 1997). Lead, Copper, Chromium, Nickel and Iron are some of the metals found in used motor oils. (Saif-ur-Rehman et al., 2018). Petroleum, pesticides or other toxic organic matter discharged into water bodies are sources of hydrocarbon pollutants (Abha and Singh, 2012).

Many bacteria and yeasts have acquired the ability to utilize hydrocarbons as sources of carbon and energy, due to the high energy content of the petroleum hydrocarbons (Yakimov et al., 2007; Gertler et al., 2009). Physico-chemical methods to control pollution have often increased the problem rather than eliminate it (Ekanem and Ogunjobi, 2017). Costsaving and environmentally friendly features are amongst the major advantages of bioremediation compared to both physical and chemical methods of remediation (Christopher et al., 2016). The success of bioremediation techniques, when applied to hydrocarbon-polluted environments, is highly dependent on the biodegrading capabilities of native microbial populations used as inoculants (Venosa and Zhu, 2003; Díaz-Ramírez, et al., 2008).

The microbial communities associated

with hydrocarbons become adapted, exhibiting selective enrichment and genetic changes (Leahy and Colwell, 1990; Atlas and Bartha, 1998). The adapted microbial communities can utilize hydrocarbon pollutants (Atlas and Bartha, 1998) and perform degradation at higher rates when compared with those in the environments that have no history of hydrocarbon pollution (Leahy and Colwell, 1990). The ability to isolate certain oildegrading bacteria and yeast in high numbers from an environment is seen as evidence that those bacteria and yeast isolates are the most active oil degraders in such polluted environments (Atlas and Bartha, 1998). Indigenous microorganisms present in contaminated environments hold the key to solving most of the challenges associated with biodegradation and bioremediation of polluted sites (Verma and Jaiswal, 2016). Individual bacteria and yeasts utilize only a limited range of hydrocarbon substrates and since crude oil is a mixture of compounds (Briton 1984; AL-Saleh et. al., 2009), biodegradation of petroleum hydrocarbon requires mixed bacterial consortia functioning to degrade a wider range of hydrocarbons (AL-Saleh, et al., 2009: Bordenave et al., 2007).

Through years of intensive study, environmental biotechnologies have devised a method of combating the problems of pollution through a technique known as bioremediation (Ekanem and Ogunjobi, 2017). Bioremediation is a technology used in the removal of environmental contaminants from the ecosystem (Omena and Olubukola, 2017). Bioremediation makes use of the catabolic activities of indigenous hydrocarbon metabolizing bacteria to decontaminate environments polluted with hydrocarbons (Mahmoud et al., 2009). It is a process by which naturally occurring microorganisms metabolize the pollutants to harmless end products (Fletcher, 2002).

There are three approaches to bioremediation: natural attenuation, sometimes called intrinsic bioremediation (relying on natural organisms for biodegradation to occur); bio augmentation (this involves adding exogenous microorganisms to supplant the natural degradation ability of the hydrocarbon-contaminated ecosystem) for in situ biodegradation and this has been applied several times at field scale levels with different degrees of success and bio stimulation (in which natural activities are stimulated by the addition of fertilizer, to improve rates of biodegradation); (Kaplan and Kitts 2004; Prince and Atlas 2005; Chikere et al., 2009 ; Gertler et al., 2009).

The harmful effect of environmental pollutants on humans is a cause for serious concern. Humans can be exposed to high amounts of oil concentration when they consume fish, animals and food crops contaminated with hydrocarbons. There could be possible damage to the bone marrow, an increased risk of cancer, development of liver or kidney disease, as a result of prolonged exposure and high amounts of oil concentration (Lloyd and Cackette, 2001; Mishra et al., 2001).

Since Panteka Stream is used for irrigation farming, fishing, and drinking purposes, the hydrocarbon pollution in the stream may cause the plants and fishes to have retarded growth or even die off, and if they survive, they could pose a health threat for the consumers. Also, when humans and cattle drink from the stream, it could be hazardous and lead to toxicity. This study aims to isolate indigenous bacteria from a hydrocarbon polluted stream, and test their potential for bioremediation. 


\section{Materials and Methods}

Natural attenuation and Biostimulation (using microbial growth nutrients) methods were used exsitu, to assess the bioremediation potentials of the isolates.

\section{Sample collection}

In the course of this study, four sampling points were identified. The first sampling point is the entry point of Panteka stream (A), which is at Rafin Guza (upstream), Sampling Point B was the beginning of the stream in Panteka Market, Sampling point $C$ was towards the end of Panteka Market, Sampling Point D is that part of the stream that flows through National Eye Centre (Downstream). Water samples were collected into four different containers and labelled accordingly. Collected samples were taken to Nigerian Defence Academy, Medical Centre Laboratory for microbiological analysis.

\section{Isolation of bacteria with hydrocarbon- degrading potentials}

Using the pour plate method, the bacteria were isolated by inoculating the samples on autoclaved selective Bushnell Haas Agar (BHA consisting of $\mathrm{MgSO}_{4} 0.2 \mathrm{~g} / \mathrm{L} \quad, \mathrm{CaCl}_{2} 0.02 \mathrm{~g} / \mathrm{L} \quad, \mathrm{K}_{2} \mathrm{HPO}_{4} 1 \mathrm{~g} / \mathrm{L}$ ， $\mathrm{KH}_{2} \mathrm{PO}_{4} 1 \mathrm{~g} / \mathrm{L}, \mathrm{NH}_{4} \mathrm{NO}_{3} 1 \mathrm{~g} / \mathrm{L} \quad \mathrm{FeCl}_{2} 0.05 \mathrm{~g} / \mathrm{L}$ and Agar $20 \mathrm{~g} / \mathrm{L} \quad$ ) medium supplemented with spent petroleum engine oil. The samples from the contaminated sites were inoculated and incubated at room temperature for 3 days. The bacteria were isolated and subcultured to obtain pure cultures.

\section{Identification of isolated bacteria}

Bacterial isolates were identified based on their morphological characteristics like colour, shape, texture, elevation form, Gram staining and biochemical tests. Molecular methods were also used to confirm the identity of one of the isolates.

\section{Isolation of genomic DNA of the bacterial isolates}

Bacterial cell suspension of $200 \mu \mathrm{L}$ was added in a 1.5 $\mathrm{mL}$ Eppendorf tube. Four hundred microliters of lysis buffer and $25 \mu \mathrm{L}$ Proteinase $\mathrm{K}$ was added to the sample in $1.5 \mathrm{~mL}$ Eppendorf tube. The tube was placed on a heat block at $60^{\circ} \mathrm{C}$ for a minimum of $1 \mathrm{~h}$. Four hundred microliters of phenol chloroform (1:1) was added to the lysate and vortexed briefly. This was spun at $10000 \mathrm{rpm}$ for $10 \mathrm{~min}$ to separate the phases. The upper layer was carefully removed with a micropipette into a new $1.5 \mathrm{~mL}$ Eppendorf tube. An equal volume of $100 \%$ ethanol was added with $20 \mu \mathrm{L}$ of $3 \mathrm{M}$ sodium acetate and mixed by inverting the tube several times which was incubated at $-20^{\circ} \mathrm{C}$ overnight. The tube was spun at a maximum speed for $30 \mathrm{~min}$. Then, $70 \%$ ethanol was added and spun at a maximum speed for $5 \mathrm{~min}$ at $4^{\circ} \mathrm{C}$. All traces of ethanol were removed by spinning for another $30 \mathrm{~s}$. The DNA was dried by leaving the tube open for 10 min. The pellet was re suspended in 20 to $50 \mu \mathrm{L}$ sterile water and the DNA quality was determined using a spectrophotometer (Jyothi et al., 2012).

\section{Polymerase chain reaction (PCR), for the} amplification of $16 S$ rRNA genes

The universal primers for 16S rDNA primers (Forward, GGACTACAGGGTATCTAAT) and (Reverse, AGAGTTTGATCCTGG) (Kenneth et. al., 1990), were used for amplification of the target genes. The PCR conditions were Pre- denaturation: $5 \mathrm{~min}$ at $94^{\circ} \mathrm{C}$, Denaturation: $1 \mathrm{~min}$ at $94^{\circ} \mathrm{C}$, Annealing: $1 \mathrm{~min}$ at $52^{\circ} \mathrm{C}$, Extension: $1 \mathrm{~min}$ at $72^{\circ} \mathrm{C}$, Final extension: 5 min at $72^{\circ} \mathrm{C}$ for 35 cycles. Analysis of the PCR products was carried out by electrophoresis in $1.5 \%$ agarose gel. This was stained with ethidium bromide and visualized under short wavelength UV light.

Nucleotide sequencing and alignment The sequencing of the amplified 16S rDNA gene was carried out using the dye terminator cycle sequencing (Quick start kit - DTCS Quick start master mix 8.0ul) in a DNA Lab . in Kaduna. Comparison was made between the gene sequences of the isolates and known nucleotide database at the National Center for Biotechnology Information (NCBI), using the Basic Local Alignment Search Tool (BLAST) algorithm (Jyothi et. al., 2012).

Tolerance of the bacterial isolates to $1 \%$ engine oil This was done to test whether the isolates possess the potential to utilize the spent engine oil. The bacterial growth was determined using turbidi metry. This was done by assessing the ability of the bacteria to utilize hydrocarbons using $1 \%$ used engine oil given as the sole carbon source in Mineral salts medium broth consisting of $\mathrm{MgSO}_{4} .7 \mathrm{H}_{2} \mathrm{O} 0.2 \mathrm{~g} / \mathrm{L}$ , $\mathrm{CaCl}_{2} .2 \mathrm{H}_{2} \mathrm{O} 0.01 \mathrm{~g} / \mathrm{L} \quad, \mathrm{K}_{2} \mathrm{HPO}_{4} \mathrm{gg} / \mathrm{L} \quad, \mathrm{NH}_{4} \mathrm{NO}_{3}$ $1 \mathrm{~g} / \mathrm{L} \quad, \mathrm{FeSO}_{4} .6 \mathrm{H}_{2} \mathrm{O} 1 \mathrm{mg} / \mathrm{L} \quad, \mathrm{ZnSO} 4.7 \mathrm{H}_{2} \mathrm{O}$ 1mg/L . The broth was inoculated with each isolated bacterium and incubated at room temperature for 16 days. The tubes were shaken. The growth of individual bacterium and mixed bacterial growth were measured and the Optical Density (O.D) readings at $600 \mathrm{~nm}$ were taken at Day 0, 2, 4, 6, 8, 10, 12, 14 and 16 respectively; mineral salt medium (MSM) containing $1 \%$ of the used engine oil served as the blank (Jyothi et al., 2012).

\section{Bioremediation Potentials of the isolated bacteria}

Two glass jars containing stream water of approximately $800 \mathrm{~mL}$ was used for the work. $100 \mathrm{~mL}$ of nutrient broth was added to both jars and 
sterilized. Mixed Bacteria Consortium (consisting of P2h1, P2h2, P3h1, P3h2, and P3h3) was inoculated into the second jar after cooling. The first jar which served as the control was left un-inoculated. The treated samples were allowed to stand for 28 days and the Total Petroleum hydrocarbon was measured using GC-FID. Comparison was done on the values obtained based on the percentage reduction after treatment.

Statistical Analysis between P3h2 and the Mixed bacterial culture

The turbidi metry test data obtained for the mixed bacterial culture and the most efficient pure Table 1: Morphological Identification of the Bacterial isolates. isolate (P3h2) in the utilization of spent engine oil were compared using student $\mathrm{t}$ - test.

\section{Results}

Morphological and Biochemical Characterization of the Bacterial Isolates obtained from Panteka Stream

The morphological and biochemical characterization identified the isolates as Streptococcus pneumoniaee (P2h1), Klebsiella pneumoniae (P2h2), Shigella dysentriae (P3h1), Streptococcus pyogenes (P3h2) and Salmonella enterica (P3h3) (Tables 1 and 2).

\begin{tabular}{|c|c|c|c|c|c|}
\hline Characteristics & P2h1 & $\mathrm{P} 2 \mathrm{~h} 2$ & P3h1 & P3h2 & $3 \mathrm{~h} 3$ \\
\hline Form & Rounded & Irregular & Round & Round & Round \\
\hline Colour & Cream & Grey & Colourless & Cream & $\begin{array}{l}\text { Black } \\
\text { pigment }\end{array}$ \\
\hline Elevation & Raised & Raised & Convex & Raised & Raised \\
\hline Shape & Diplococci & Rod & Rod & Cocci & Rods \\
\hline Gram staining & + & - & - & + & - \\
\hline $\begin{array}{l}\text { Likely } \\
\text { Bacteria }\end{array}$ & $\begin{array}{l}\text { Streptococcus } \\
p \quad \text { neumoniae }\end{array}$ & $\begin{array}{l}\text { Klebsiella } \\
p \quad \text { neumoniae }\end{array}$ & $\begin{array}{l}\text { Shigella } \\
\text { dysenteriae }\end{array}$ & $\begin{array}{c}\text { Streptococcus } \\
p \text { yogenes }\end{array}$ & $\begin{array}{l}\text { Salmonella } \\
e \quad \text { nterica }\end{array}$ \\
\hline
\end{tabular}

Table 2: Biochemical Identification of bacteria isolates

\begin{tabular}{|l|l|l|l|l|l|}
\hline & P2h1 & P2h2 & P3h1 & P3h2 & P3h3 \\
\hline Mannitol & - & + & - & - & + \\
\hline $\begin{array}{l}\text { Orthinine } \\
\text { decarboxylate }\end{array}$ & - & - & - & - & - \\
\hline $\begin{array}{l}\text { Nitrate } \\
\text { reduction }\end{array}$ & - & - & - & - & - \\
\hline Urease & - & + & - & - & - \\
\hline Catalase & - & - & - & - & + \\
\hline Gas & & + & - & & + \\
\hline Coagulase & - & - & - & - & - \\
\hline Indole & - & - & - & - & - \\
\hline Lactose & - & - & - & - & - \\
\hline SSA & - & - & + & - & + \\
\hline KIA & - & - & - & NA & + \\
\hline Optochin disc & + & NA & NA & NA & NA \\
\hline Methyl red & NA & - & NA & NA & NA \\
\hline Citrate & NA & + & NA & NA & + \\
\hline
\end{tabular}




\begin{tabular}{|c|c|c|c|c|c|}
\hline $\begin{array}{l}\text { Haemolysis on } \\
\text { blood agar }\end{array}$ & + & - & - & + & - \\
\hline $\begin{array}{l}\text { Hydrogen } \\
\text { sulphide }\end{array}$ & - & - & - & - & + \\
\hline Oxidase & - & - & - & - & - \\
\hline Motility & - & - & - & - & + \\
\hline $\begin{array}{l}\text { MacConkey } \\
\text { Agar }\end{array}$ & + & + & - & - & + \\
\hline \multicolumn{6}{|l|}{ Likely } \\
\hline $\begin{array}{l}\text { Bacterial } \\
\text { Isolates }\end{array}$ & $\begin{array}{l}\text { Streptococcus } \\
\text { pneumoniae }\end{array}$ & $\begin{array}{l}\text { Klebsiella } \\
\text { pneumoniae }\end{array}$ & $\begin{array}{l}\text { Shigella } \\
\text { dysenteriae }\end{array}$ & $\begin{array}{l}\text { Streptococcus } \\
\text { pyogenes }\end{array}$ & $\begin{array}{l}\text { Salmonella } \\
\text { enterica }\end{array}$ \\
\hline
\end{tabular}

Key: + Positive, - Negative, KIA- Kligler iron agar, SSA - Salmonella Shigella agar, NA- Not applicable.

\section{Bacterial Identification by 165 rRNA Gene Analysis}

PCR amplification of the 16S rRNA gene produced fragments of approximately 800 base pairs in size for the five bacteria isolates. Full length sequence of the bacteria gene was obtained. Using BLAST, the closest match was detected. In addition to the biochemical identification of P3h3, 16S rRNA gene sequencing confirmed the identity of one isolate, Salmonella enterica with $99 \%$ similarity (Figure 1 ).

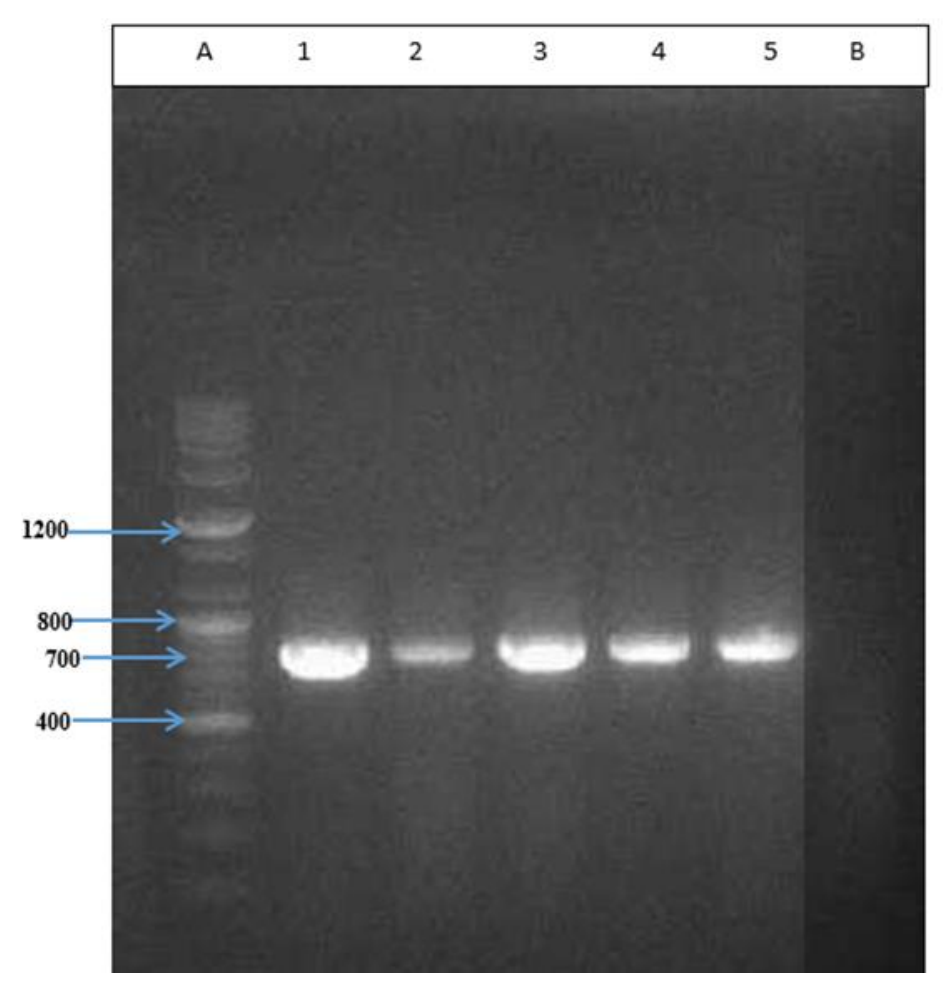

Fig. 1: $P C R$ amplicons of rRNA genes in five bacteria isolates from Panteka stream. Lane A- Ladder, Lane 1 P2H1, Lane 2 - P2H2, Lane 3- P3H1, Lane 4 - P3H2, Lane 5 - P3H3, Lane B- Negative control.

\section{Tolerance of the Bacteria isolates to $1 \%$ Engine oil}

The turbidi metry test showed that the five bacterial isolates exhibited lag phase except for the mixed bacterial consortium. The five bacterial isolates were found to attain the initial exponential phase at Day 2 and their maximum exponential phase between Days 10 and 14 . The MBC attained maximum exponential phase on Day 14. Each of the five isolates exhibited a stationary phase between Days 10 and 14. All the five isolates and MBC showed a decline phase on Day 16. 
The MBC had the highest growth rate (0.695), followed by $S$. pyogenes (0.565), S. enterica (0.465), $S$. dysenteriae (0.435), K. pneumoniae $(0.43), S$. pneumoniae (0.355). S. pyogenes was the most efficient single isolate.

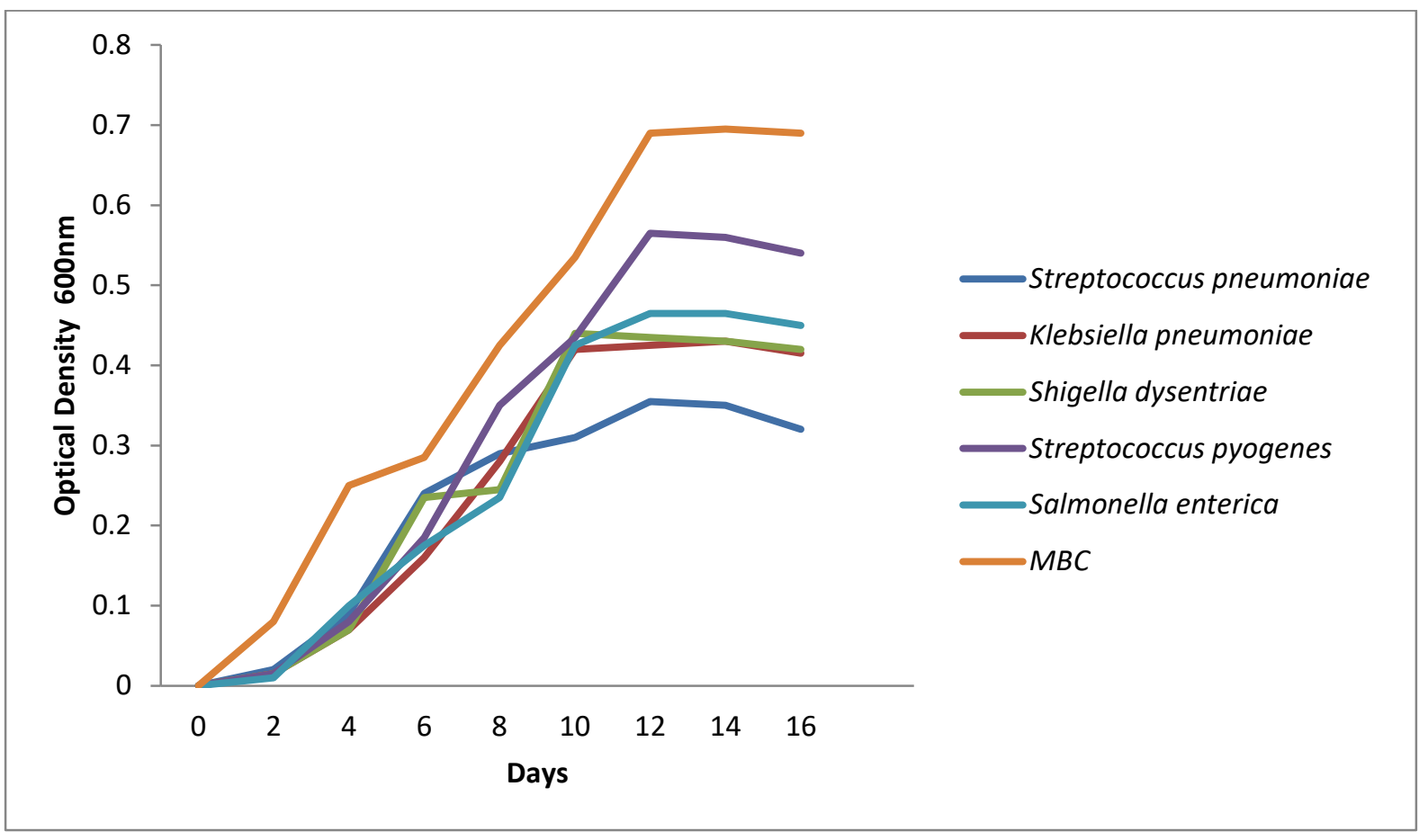

Fig 2: Growth rate of the five bacteria isolates and $M B C$ in $1 \%$ spent engine oil

\section{Degradation Potential of the Isolates}

The GC-FID chromatograms of the stream water before subjection to biodegradation by MBC (Figure 3) and after a 28-day treatment by MBC is shown in Figure 4 . After treatment with the consortium of bacteria, the data show a reduction in the intensity of the hydrocarbon peaks when compared to the untreated stream water (Figure 3) as well as differences in the profile of their hydrocarbon fractions (Table 3). Pristane and Phytane (biomarkers of crude oil) were among the hydrocarbon fractions present in the Stream water (Table 3). The TPH obtained before treatment of the stream water was $6,056 \mathrm{mg} / \mathrm{ml}$ whereas after treatment with $\mathrm{MBC}$, it became $100.17 \mathrm{mg} / \mathrm{ml}$ ( $98.3 \%$ reduction).

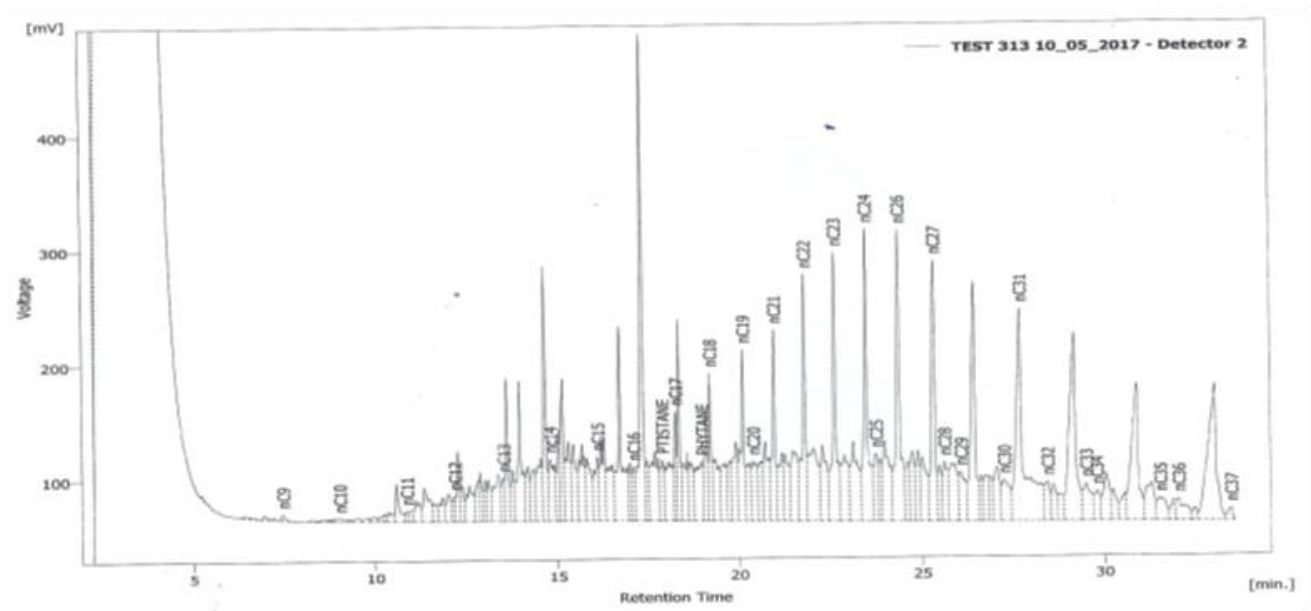

Fig 3: Chromatogram of stream water before treatment with MBC 


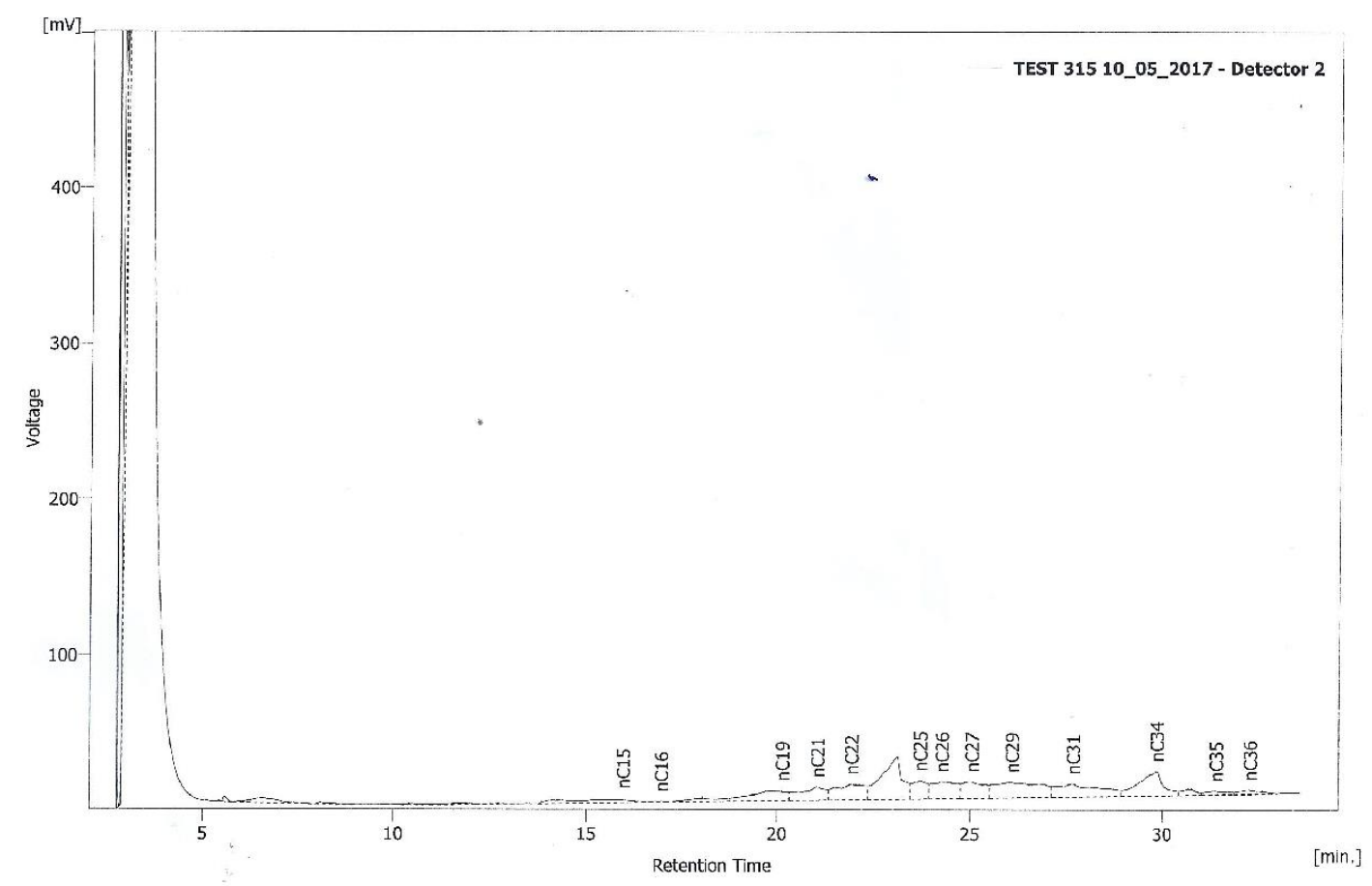

Fig 4: Chromatogram of stream water after treatment with MBC

Table 3: Hydrocarbon fractions present in sample before and after treatment

\begin{tabular}{|c|c|c|c|}
\hline \multicolumn{2}{|c|}{ Before treatment with $\mathrm{MBC}$} & \multicolumn{2}{|c|}{ After treatment with MBC } \\
\hline & n-Nonane & $\mathrm{nC}_{15}$ & n-Pentadecane \\
\hline $\mathrm{nC}_{10}$ & n-Decane & $\mathrm{nC}_{16}$ & n-Hexadecane \\
\hline $\mathrm{nC}_{11}$ & n-Undecane & $\mathrm{nC}_{19}$ & n-Nonadecane \\
\hline $\mathrm{nC}_{12}$ & n-Dodecane & $\mathrm{nC}_{21}$ & n-Heneicosane \\
\hline $\mathrm{nC}_{13}$ & $\mathrm{n}$-Tridecane & $\mathrm{nC}_{22}$ & n-Docosane \\
\hline $\mathrm{nC}_{14}$ & $\mathrm{n}$-Tetradecane & $\mathrm{nC}_{25}$ & n-Pentacosane \\
\hline $\mathrm{nC}_{15}$ & n-Pentadecane & $\mathrm{nC}_{26}$ & n-Hexacosane \\
\hline $\mathrm{nC}_{16}$ & n-Hexadecane & $\mathrm{nC}_{27}$ & n-Heptacosane \\
\hline $\mathrm{nC}_{17}$ & n-Heptadecane & $\mathrm{nC}_{29}$ & n-Nonacosane \\
\hline iC $C_{17}$ & Pristane (biomarker) & $\mathrm{nC}_{31}$ & n-Hentriacontane \\
\hline $\mathrm{nC}_{18}$ & n-Octadecane & $\mathrm{nC}_{34}$ & $\mathrm{n}$-Tetratriacontane \\
\hline $\mathrm{iC}_{18}$ & Phytane (biomarker) & $\mathrm{nC}_{35}$ & n-Pentatriacontane \\
\hline $\mathrm{nC}_{19}$ & n-Nonadecane & $\mathrm{nC}_{36}$ & n-Hexatriacontane \\
\hline $\mathrm{nC}_{20}$ & n-Eicosane & & \\
\hline $\mathrm{nC}_{21}$ & n-Heneicosane & & \\
\hline $\mathrm{nC}_{22}$ & n-Docosane & & \\
\hline $\mathrm{nC}_{23}$ & n-Tricosane & & \\
\hline $\mathrm{nC}_{24}$ & n-Tetracosane & & \\
\hline $\mathrm{nC}_{25}$ & n-Pentacosane & & \\
\hline $\mathrm{nC}_{26}$ & n-Hexacosane & & \\
\hline $\mathrm{nC}_{27}$ & n-Heptacosane & & \\
\hline $\mathrm{nC}_{28}$ & n-Octacosane & & \\
\hline $\mathrm{nC}_{29}$ & n-Nonacosane & & \\
\hline $\mathrm{nC}_{30}$ & n-Triacontane & & \\
\hline $\mathrm{nC}_{31}$ & n-Hentriacontane & & \\
\hline $\mathrm{nC}_{32}$ & n-Dotriacontane & & \\
\hline
\end{tabular}




\begin{tabular}{|ll|l|}
\hline $\mathrm{n} C_{33}$ & $\mathrm{n}$-Tritriacontane & \\
\hline $\mathrm{nC}_{34}$ & $\mathrm{n}$-Tetratriacontane & \\
\hline $\mathrm{nC}_{35}$ & $\mathrm{n}$-Pentatriacontane & \\
\hline $\mathrm{n} \mathrm{C}_{36}$ & $\mathrm{n}$-Hexatriacontane & \\
\hline $\mathrm{nC}_{37}$ & $\mathrm{n}$-Heptatriacontane & \\
\hline
\end{tabular}

\section{Statistical Analysis}

Student's t - test comparison between MBC and Streptococcus pyogenes.

\begin{tabular}{|l|l|l|}
\hline Days & MBC & Streptococcus pyogenes \\
\hline 0 & 0 & 0 \\
\hline 2 & 0.08 & 0.015 \\
\hline 4 & 0.25 & 0.08 \\
\hline 6 & 0.285 & 0.185 \\
\hline 8 & 0.425 & 0.35 \\
\hline 10 & 0.535 & 0.435 \\
\hline 12 & 0.69 & 0.565 \\
\hline 14 & 0.695 & 0.56 \\
\hline 16 & 0.69 & 0.54 \\
\hline & & \\
\hline $\mathrm{n}=9$ & $\mathrm{~S}_{1}{ }^{2}=0.25$ & $\mathrm{~S}_{2}{ }^{2}=0.22$ \\
\hline & $\mathrm{X}_{1}=0.41$ & $\mathrm{X}_{2}=0.30$ \\
\hline
\end{tabular}

$\mathrm{T}$ calculated $=0.482$, at $95 \%$ confidence limits, $\mathrm{t}_{0.05}$ at degree of freedom $(\mathrm{df}),=16, \mathrm{t}$ tabulated $=2.120, \mathrm{t}$ cal $<\mathrm{t}$ tab. The $\mathrm{P}$ - values $(\mathrm{P}>0.05)$ showed no significant difference in the growth rate readings between MBC and $S$. pyogenes, therefore, the null hypothesis was not rejected.

\section{Discussion}

The five isolates were identified based on their colony characteristics like shape, colour, texture, form, elevation and biochemical tests.

Five hydrocarbon- tolerant bacteria were isolated and identified as Streptococcus pneumoniae, Klebsiella pneumoniae, Shigella dysenteriae, Streptococcus pyogenes and Salmonella enterica. The bacteria genera found are in line with a previous report by Eze et al., (2006) who also isolated Enterobacter, Klebsiella spp, and Streptococcus spp. All the hydrocarbon- tolerant bacteria isolated were either pathogens or enteric, that could have found themselves in Panteka stream as a result of poor sanitary conditions around the stream and its environments. The bacteria could have adapted to this environment, thereby utilizing the hydrocarbons in the stream as a source of carbon resulting in their being hydrocarbonoclastic bacteria.
All the five bacterial isolates showed tolerance to $1 \%$ engine oil. They exhibited lag, exponential stationary and decline phases of growth (Figure 2). This result compares favourably to the work of Chioma et al., (2016) on hydrocarbon degradation where the bacteria species isolated exhibited similar growth phases. In this study, the potential of the bacteria to utilize engine oil as a sole carbon source is listed in decreasing order of MBC (0.695), Streptococcus pyogenes (0.565), Salmonella enterica (0.465), Shigella dysentriae (0.435), Klebsiella pneumoniae (0.43) and Streptococcus pneumonia (0.355). The results showed that a mixed culture of the hydrocarbonoclastic bacteria was more effective in degrading hydrocarbons in the stream than individual pure cultures of the isolates. This compared favourably to the report of Adebusoye et al., (2007) which indicated that a mixed culture exhibited a superior degradative competence for hydrocarbon degradation than the individual bacterial strains .

The mixed bacterial culture was used to determine the bioremediation potential of the 
hydrocarbonoclastic bacteria on the hydrocarbons present in the Panteka stream. Cooperation of more than a single species is usually required for the biodegradation of complex hydrocarbons, such as petroleum where complete mineralization to carbon dioxide and water is desired (Farinazleen, et. al., 2004). Only a limited range of hydrocarbon substrates can be metabolized by individual microorganisms; in order to increase the rate and extent of petroleum biodegradation, assemblages of mixed populations with overall broad enzymatic capacities are required (Farinazleen, et al., 2004).

Based on the turbidi metry results, it was obvious that the MBC was better than the individual isolates, therefore, only GC-FID for MBC was performed. The GC-FID chromatogram in Figures 3 and 4 revealed that at the end of 28 days, the hydrocarbon fractions reduced from 31 to 13 during the degradation of the hydrocarbon fractions. The low molecular weight hydrocarbons $\mathrm{nC}_{9}-\mathrm{nC}_{14}$ were degraded. Samaei et al., (2014) stated that middle- length chain ( $C_{10}$ $\mathrm{C}_{25}$ ) n-alkanes are the preferred substrates for the organisms and are most quickly degradable by them. This could explain why the mixed bacterial culture was able to degrade n-alkanes with short- and middle- length chains in this study. However, some long- chain alkanes $\left(\mathrm{nC}_{20}, \mathrm{nC}_{23}, \mathrm{nC}_{24}, \mathrm{nC}_{28}, \mathrm{nC}_{30}\right.$, $\mathrm{nC}_{32}, \mathrm{nC}_{33}$, and $\mathrm{C}_{37}$ ) which had higher molecular weights were also degraded. This might have occurred as a result of their being less toxic to the MBC.

The mixed bacterium consortium was capable of degrading pristane and phytane. Solano-Serena et al., (2004), stated that several bacterial strains are capable of degrading branched-chain alkanes such as pristane or isooctane. This contrasts the findings of Paudyn et al., (2008) who stated that isoprenoids are resistant to biodegradation due to their branched nature and when compared to linear ones, they are more slowly degraded. It has been reported that pristane is a recalcitrant compound for attack by microorganisms (Farinazleen, et al., 2004). Pristane has been commonly used as a chemical marker against which other biodegraded compounds are measured throughout a bioremediation study, due to its resistance to biodegradation (Olivera et al., 2000; Wang et al., 1998). The hydrocarbon fractions that were not degraded might be as a result of their toxicity to the bacteria or the inability of the mixed bacteria culture to produce enzymes that can degrade the hydrocarbon component. Heipieper and MartinezLavanchy, (2010) stated that several classes of organic compounds are toxic for living organisms.
The T-test done to evaluate the difference in the growth rates between the mixed bacterial isolates and the $S$. pyogenes in the utilization of $1 \%$ engine oil for 16 days showed that MBC and $S$. pyogenes growth rates were not significantly different $(P>$ 0.05).

From this study, it is evident that the Panteka stream is indeed polluted. The high concentrations of these pollutants in the stream could have negative effects on animal and human health. The public should be enlightened on the health and environmental impact of incessant disposal of used petroleum products into the stream.

The observation that the MBC in this study, obtained a $98.3 \%$ degradation rate, and degraded pristane, phytane and long chain alkane such as $\mathrm{nC}_{37}$, showed that it has the potential to decontaminate hydrocarbon- polluted sites, with reference to Panteka stream in Kaduna.

\section{Acknowledgements}

Our appreciation goes to the Laboratory staff of the Nigerian Defence Academy Medical Centre for giving us the opportunity to use their facilities, and technical support throughout the course of this research work. We also appreciate the supports of the staff of Thermosteel Nigeria Limited (Environmental consultancy and Analytical Laboratory) in Warri, Delta state. A special thanks goes to Dr. Nkechi Egbe and Dr. Victoria Dan who took out their time to supervise this work.

\section{References}

Abdulsalam, S., Adefila, S.S., Bugaje, I.M. and Ibrahim, S. (2013). Bioremediation of Soil Contaminated With Used Motor Oil in a Closed System. J. Bioremediat. Biodegrad. 4:172.

Abha, S. and Singh, C.S. (2012). Hydrocarbon Pollution; effects on living organisms, Remediation of contaminated environments and effects of heavy metals co '-contamination on bioremediation. In: Introduction to enhanced oil on recovery (EOR). Processes and Bioremediation of oil contaminated sites, Romero- Zeron, L. (Ed). InTech Publisher, China. 186-206.

Adebusoye, S.A., Ilori, M.O., Amund, O.O., Teniola, O.D., Olatope, S.O. (2007). Microbial degradation of petroleum hydrocarbons in a polluted tropical stream. World J. Microb. Biot. 23(8): 1149-1159. 
AL-saleh, E., Drobiova, H. and Obuekwe, C. (2009). "Predominant culturable crude oil-degrading bacteria in the coast of Kuwait," Int. Biodeter. Biodegr. 63(4): 400-406.

Atlas, R.M. and Bartha, R. (1998). Microbial Ecology: Fundamentals and Applications, Benjamin/Cummings Publishing Company, Inc., An imprint of Addison Wesley Longman, Inc, Menlo Park, Calif, USA, 4th edition.

Bordenave, S., Goñi-Urriza, M.S., Caumette, P. and Duran, R. (2007). "Effects of heavy fuel oil on the bacterial community structure of a pristine microbial mat," Appl. Environ. Microbiol. 73 (19): 6089-6097.

Britton, L.N. (1984). "Microbial degradation of aliphatic hydrocarbons," in Microbial Degradation of Organic Compounds, D. T. Gibson, Ed., pp. 89-129, Marcel Dekker, New York, NY, USA, 1984.

Chikere, C.B., Okpokwasili, G.C. and Chikere, B.O. (2009). Bacterial diversity in tropical crude oilpolluted soil undergoing bioremediation. Afr. J. Biotechnol. 8: 253-2540.

Chioma, B.C., Amara, U.O. and Gideon, C.O. (2016). "Microbial community profiling of active oleophilic bacteria involved in bioreactor-based crude-oil polluted sediment treatment. Appl. Environ. Microbiol. 4 (1): 1-20.

Christopher, C.A., Chioma, B.C., and Gideon, C.O. (2016). Bioremediation techniques-classification based on site of application: principles, advantages, limitations and prospects. World J. Microb. Biot. 32 (11): 180 .

Díaz-Ramírez, I.J., Escalante-Espinosa, E., FavelaTorres, E., Gutiérrez-Rojas, M. and H. Ramírez-Saad. (2008). "Design of bacterial defined mixed cultures for biodegradation of specific crude oil fractions, using population dynamics analysis by DGGE, "Int. Biodeter. Biodegr. 62 (1): 21-30.

Dorsey Jr A.S., Rabe, C. and Thampi, S. (1997). Toxicological profile for used mineral-based crankcase oil. Agency for Toxic substances and Disease Registry, U. S. Department of health and human services.

Ekanem, J.O. and Ogunjobi, A.A. (2017). Hydrocarbon Degradation Potentials of Bacteria Isolated from Spent Lubricating Oil Contaminated Soil. J. Appl. Sci. Environ. 21 (5): 973-979

Eze, V.C., Okwulume, C.O. and Agwung, F.D. (2006). Biodegradation of palm oil polluted site Int. J. Biotechnol. Allied Sci. 1(1), $58-65$.
Farinazleen, M.G., Raja, N.Z.A., Abu Bakar, S. and Mahiran, B. (2004). Biodegradation of hydrocarbons in soil by microbial consortium. Int. Biodeter. Biodegr. 54: $61-67$.

Fletcher, R.D. (2002). Bioremediation of Aviation Oil Spill: An Environmental Alternative. J. Ind. Microbiol. 7 (1): 28-111.

Gertler, C., Gerdts, G., Timmis, K.N., Yakimov, M.M. and Golyshin, P.N. (2009). Populations of heavy fuel oil-degrading marine microbial community in presence of oil sorbent materials. J. Appl. Microbiol. 107:590-605.

Heipieper, H. and Martinez-Lavanchy, P. (2010). Toxicity of hydrocarbons to microorganisms.10.1007/978-3-540-77587-4-108.

Jyothi, K., Surendra, B.K., Nancy, C.K. and Kashyap, A. (2012). Identification and Isolation of Hydrocarbon Degrading Bacteria by Molecular Characterization. Helix. 2:105-111.

Kaplan, C.W. and Kitts, C.L. (2004). Bacterial succession in a petroleum land treatment unit. Appl. Environ. Microbiol.70: 1777-1786.

Leahy, J.G. and Colwell, R.R. (1990). Microbialdegradation of hydrocarbons in the environment. Microbiol. Rev. 54:305-315

Lloyd, C.A. and Cackette, T.A. (2001). Diesel engines: Environmental impact \& control. Air and waste management Association, 51: 805-847.

Mahmoud, H.M., Al-Hasan, R.H., Sorkhoh, N.A., Eliyas, M. and Radwan, S.S. (2009). Attenuation of oil pollutants in the Arabian Gulf water by bacteria naturally associated with live fish. Int. Biodeter. Biodegr. 63: 615-620.

Mishra, S., Jyot, J., Kuhad, R.C. and Lal, B. (2001). Evaluation of inoculum addition to stimulate in situ bioremediation of oily-sludge-contaminated soil. Appl. Environ. Microbiol. 67: 1675-1681.

Olivera, N.L., Commendatore, M.G., MorWan, A.C. and Esteves, J.L. (2000). Biosurfactant-enhanced degradation of residual hydrocarbons from ship bilge wastes. J. Ind. Microbiol. Biot. 25:70-73.

Omena B.O. and Olubukola, O.B. (2017). Microbial and Plant-Assisted Bioremediation of Heavy Metal Polluted Environments: A Review. Int. J. Environ. Res. Public Health. 14 (12): 1504. 
Paudyn, K., Rutter, A., Rowe, R.K. and Poland, J.S. (2008). Remediation of hydrocarbon contaminated soils in the Canadian Arctic by Landfarming. Cold Reg. Sci. Technol. 53: 102-114.

Prince, R. and Atlas R.M. (2005). Bioremediation of marine oil spills. In: Atlas RM, Philp J, editors. Bioremediation: applied microbial solutions for real-world environmental cleanup. Washington DC: American Society for Microbiology (ASM) Press; 2005. pp. 269-292.

Saif-ur-Rehman, K., Aneesa, Z., Fariha, A. and Zubair, F. (2018). Comparison of heavy metals in fresh and used engine oil. Pet. Sci. Technol. 36:18, 1478-1481.

Samaei, M.R., Mortazavi, S.B., Jonidi, J.A. and Bakhshi, B. (2014). Isolation, biodegradation ability, and molecular detection of $\mathrm{n}$-Hexadecane degrading bacteria from compost. Proc., Second Int. Conf. on Environmental science and Technology, Antalya/Turkey.

Solano-Serena, F., Marchal, R., Heiss, S. and Vandecasteele, J.P. (2004). Degradation of isooctane by Mycobacterium austroafricanum IFP 2173: growth and catabolic pathway. J. Appl. Microbiol. 97: 629639.

Venosa, A.D. and Zhu, X. (2203). "Biodegradation of crude oil contaminating marine shorelines and freshwater wetlands. Spill Sci. Technol. Bull. 8 (2): 163-178.

Verma J.P, Jaiswal D.K. (2016). Book review: advances in biodegradation and bioremediation of industrial waste. Front Microbiol. 6:1-2.

Wang, Z., Fingas, M., Blenkinsopp, S., Sergy, G., Landriault, M., Sigouin, L., Foght, J., Semple, K. and Westlake, D.W.S. (1998). Comparison of oil composition changes due to biodegradation and physical weathering in different oils. J. Chromatogr. A. 809: 89-107.

Yakimov, M.M., Timmis, K.N. and Golyshin, P.N. (2007). Obligate oil-degrading marine bacteria. Curr. Opin. Biotechnol. 18: 257-266. 